\title{
The Roles of Elementary Teachers in Addressing Cultural Indifferences in the Classroom
}

DOI: 10.15804/tner.2021.64.2.16

\begin{abstract}
Cultural indifferences among students are rampant, especially in a multicultural classroom. Thus, the teachers become the front liners in addressing these differences inside the classroom. This study aimed to determine the roles of the teachers in solving cultural indifferences inside the classroom. Using the Transcendental phenomenological approach in research, the researchers explored the experiences of eight teachers in Malangas Special Education Center, Poblacion, Malangas, Zamboanga Sibugay, Philippines. These teachers have personally experienced solving cultural indifferences inside their classroom due to having students from diverse tribes. The researchers explored their experiences through one-to-one interviews during their free time in their respective classrooms. Employing the Phenomenological data analysis of Kleiman (2004), the teachers played the roles of adviser, peacemaker, listener, and guidance counselor. These roles helped them address cultural discrimination inside the classroom and establish a peaceful learning environment to facilitate learning effectively and efficiently.
\end{abstract}

Keywords: cultural indifference; phenomenology; peaceful environment; Philippines

\section{Introduction}

One of the essential characteristics of an ideal classroom is having a positive learning environment. Having a democratic classroom creates self-motivation for students to strive for success. A democratic classroom helps reinforce the management of the class and the teacher's expectations. When students come 
together in the same classroom, they exhibit different behaviors and create clashes among other students. Perso (2004) conducted a study on responsive teaching in the cultural classroom and has emphasized that cultural indifferences in the classroom have been a global problem. Malaysian schools, for example, have the challenge of multiethnic and multiracial unification (Malakolunthu, Siraj, \& Rengasamy, 2010). Thus, students are being taught intercultural awareness. They are also taught the values of co-existence and cooperation with other cultural groups in the school. Moreover, the high teacher-student ratio in some remote schools and the negative attitudes by teachers and heads affect multicultural education in schools (Mapuranga, \& Bukaliya, 2014). Teachers have discomforting emotions towards growing diversity and Multiculturalism in their workplace (Zembylas, 2010).

In the research locale, the teachers find it challenging to teach and discipline these students from diverse cultures and sub-cultures (Ramirez, 2006). These students sometimes encounter problems with their co-students. Because of the history of conflicts, students coming from different tribes have biases (Tawagon, 2008). These biases result in bullying experiences such as physical, verbal-relational, and cyberbullying (Ouano, Buot, Conway, \& Dela Rosa, 2013). So, teachers need to employ different strategies to prevent and solve conflicts. They need to be vigilant in addressing these problems in their classrooms.

The teacher's role as the solver is fundamental in the classroom to deal with and resolve possible conflicts in his/her designated learning environment and deal with discrimination because of cultural indifferences. It is significant for teachers to develop care for the students for them to have to develop their character and create a positive connection to others (Ballada, 2014). Institutions like schools should reflect on the students' existence coming from diverse cultures (Cuyjet, Howard-Hamilton, \& Cooper, 2012). Multicultural education helps educators, especially elementary teachers, become effective facilitators in a diverse classroom (Banks \& Banks, 2019). Anchored on the theory on Multiculturalism, the researchers were enthusiastic about conducting this study on the teachers' roles in solving cultural clashes in the classroom. The study described the different roles of elementary teachers in solving cultural indifferences happening inside the classroom. This study also investigated further into how these roles helped the teacher solve cultural differences inside the classroom. 


\section{Method}

This study employed a qualitative research design using the transcendental phenomenological method (Welton, 2000). Qualitative research stresses the verbal descriptions and explanations of a particular phenomenon in the life experience of the research participants (Garcia et al., 2011). Phenomenology extracts the pattern of the research participants' experiences to describe a typical structure of their experience (Moustakas, 1994). In this study, the researchers described eight elementary teachers' experiences as they narrated their roles in addressing students' indifferences inside the classroom.

The research environment of the study is the Malangas Special Education center, Poblacion, Malangas, Zamboanga Sibugay. The school has pupils from different local tribes in the Philippines, such as Cebuano/Visayan, Subanen, Tausug, Maguindanaon, Ilonggo, Maranao, and Samal. Thus, the Malangas Special Education center is an appropriate environment for this study. The study participants were the eight teachers of Malangas, SPED center, who encountered cultural indifferences among their learners. The researchers chose the participants who have encountered cultural indifference and served as solvers to ensure that the participants could respond to the study's objectives.

The researchers were the main instrument of this study, aided by their interview guide. In the interview, the participants answered the questions based on their experiences. Hence, there were no suggested answers, but the researchers purely depended on the participant's decision-making skills, allowing them to think critically. The researchers prepared follow-up questions to strengthen the necessary information. These data from the participants in this study were gathered through in-depth interviews and considered individual interviews as its approach.

The researchers followed the phenomenological data analysis of Kleiman (2004). The researchers went through verbatim transcription, coding, and collating. In the verbatim transcription, the researchers made a written record of an interview. In the coding process, the researchers used symbols like words to represent arbitrary or subjective data to ensure the data's privacy and secrecy. After so, the researchers collated the data to bring the codes together to form themes.

The researchers observed the proper way of researching as they upheld ethical norms. Being non - maleficent, the researchers avoided harming the participants in the interview, giving them the free will to be part of the study and providing them the time to answer the questions. The researchers considered the good and positive outcome of this study that can help the research participants. The 
researchers considered the participants' autonomy and self-determination since they respected the values and decisions exhibited by the participants. They allowed the participants to freely describe their encounters in dealing with the pupils who have cultural indifference.

\section{Results of Research}

In solving cultural indifferences in the classroom, the teachers play different roles such as an adviser, a peacemaker, a listener, and a guidance counselor. Moreover, these four roles help them unite and create a positive learning environment in the classroom by avoiding cultural discrimination and establishing a peaceful learning environment. The effectiveness of these roles in addressing cultural indifferences was seen in these two themes: avoiding cultural discrimination and establishing a peaceful learning environment.

Adviser. The teachers served as an adviser in solving cultural indifference in the classroom. As an adviser, he/she gave positive opinions, valuable suggestions, specific recommendations, and provided information to lessen and stop cultural clashes in the classroom. The teacher - participants revealed:

I talk to those who are involved and give them advice, warnings or give them conditions. $-P 1$

You will give them advice because they will believe you. After all, you are their teacher. You give them suggestions to solve their problems. - P2

I always give them a piece of advice. Every day, I tell them not to fight, especially that they are still children. I tell them to understand each other because they are coming from different cultures. - P5

In settling their quarrels, especially those that involve their cultures, I advise them and give my opinion to settle the quarrel. - P6

Peacemaker. Teachers, as peacemakers, helped both parties to be reconciled to stop them from fighting and arguing. Teachers would appease the opposing students> emotional conditions to be reconciled and made peace. The participants narrated:

Sometimes when they argue about their beliefs, especially when there are topics in our lessons that are sensitive to others beliefs, I will become a peacemaker. - P1

If there are clashes because of their cultures, I will act as a peacemaker. As a peacemaker, I need to be flexible and ready to understand. - P2 
In their arguments that involve their culture as teachers, I acted as a peacemaker. I set classroom rules to promote collaboration. - P3

Peacemaker is one of my roles as a teacher. As a peacemaker, I respect them and value their feelings. - P6

Listener. Being a listener as one of the teachers` roles denotes that teachers never judge the students because of their cultures and family backgrounds. Instead, they spend time listening to their different life stories. The participants said:

Usually, I listen to each pupil's side. I suspend my judgment unless I already know the entire story. $-P 2$

When it comes to cultural indifferences, the first role of the teachers is to become a good listener. I do not judge them, yet I listen to their problems. - P4

If there are indifferences because of cultures, I always listen to both sides of the disagreement. - $P 7$

Guidance Counselor. As guidance counselors, teachers give the students guidance on what to do to stop the cultural indifference in the classroom. Teachers help the students understand the situation and their educational goals and help them in to achieve them. Teachers help the students to solve their problems. The participants explicitly said:

The most common clashes are from the Muslims and Visayan. They tease each other's dialect. So, I talk to those who are involved and guide them. - P2

As a teacher, I always give the students guidance, especially when there is cultural indifference. I offer them direction in solving their issues and conflicts. $-P 7$

You should use your role as guidance counselor when there are cultural indifferences in the classroom. It is not good to judge them but instead be helpful to them for them to become better individuals. - P8

The roles of the teachers are significant in solving cultural indifference in the classroom. These roles ensure they create a positive learning environment in the class. The participants revealed that these roles allowed them to avoid cultural discrimination and establish a peaceful learning environment.

Avoiding cultural discrimination. Teachers' roles in solving cultural indifference help the students to avoid cultural discrimination. When teachers advise, give guidance, and resolve problems, they will instill the adverse effects of cultural discrimination in the students' minds. They said: 
My role as an adviser helps me because I can talk to them to avoid cultural discrimination. I advise them to respect individual cultures. $-P 1$

In solving cultural indifference in the classroom, I ensure that I remove the cultural discrimination that usually causes conflict among my students. - P6

It helped me solve cultural indifference because, through this, the students know that they should not disrespect other cultures. - P7

Establishing a peaceful learning environment. Teachers could build a peaceful environment among students after solving cultural indifference. The teachers' role in solving cultural indifference helped them establish a peaceful learning environment whereby conflicts in cultures are not a problem. The participants stated:

If I already reprimand the children who are quarreling, then there is peace in the classroom. $-P 2$

To make the classroom peaceful, I should solve the conflict inside the class so that learning would take place. $-P 3$

The roles helped us, teachers, to make the environment peaceful. If the classroom is peaceful, students learn effectively. - P4

One of my goals in solving cultural indifference is to make the classroom peaceful. If there are quarrels, they cannot concentrate on learning in the class. - P5

My roles as a teacher would help by attaining a peaceful classroom free from any form of quarrel among my students. $-P 8$

\section{Discussion}

The responses of the elementary teachers showed that they act as advisers to their students, especially when there are cultural indifferences. Every day, teachers function as advisers by giving suggestions and opinions to maintain a positive learning environment. When cultural indifference happened, teachers tried to advise on what to do, presented their wise views, and let students understand the situation. Cultural indifference is one of the problems of the students in the classroom. Everyone is protecting and displaying their cultural background to be identified as those above other classmates (Yang et al., 2010). The teacher's role as an adviser is necessary for this phenomenon since the students would look up to them and believe them as teachers. Teachers should suggest possible solutions to stop fighting and quarreling because of culture. Schools then should look for 
ways to implement programs promoting the harmonization of the people and improving the school climate (Emmerová \& Kohútová, 2017).

The teachers can also act as peacemakers in addressing the cultural indifference in the classroom. As peacemakers, they did not judge their students. They respect their values, feelings, and varied cultures. Teachers set collaborative rules to guide the students on what to do and would also lessen the occurrence of cultural indifference. In some sensitive discussions, mainly on cultural issues, they satisfied each other's feelings. The role of the teachers as the peacemaker in the classroom is a significant aspect to solve cultural indifference in the school. Teachers should help students understand others' feelings and respect everyone's culture (Rychly \& Grave, 2010). Their peacemaker's role enables them to create a positive learning environment.

The teachers act as listeners to their students when there is cultural indifference. Their roles as listeners guide them to know the root of the conflict and lead to give solutions. Teachers understand and listen to their students' reasons to come up with a good result.

In resolving conflicts among students, teachers should never judge them but should listen to both sides to arrive at a better solution. Listening is the first step in solving cultural indifference among students (Warikoo, 2009). As they listen to the students' side, they have a chance to weigh in their reasons and provide solutions according to their problem.

The teachers act as guidance counselors when there is cultural indifference. They talk to the students as what the guidance counselors do rather than being a disciplinarian. They always assist the students on what to and help them stay focused on their studying goals. Guidance counselors never judge students; instead, they guide them to discover their skills. Teachers should be guidance counselors to help students reach their goals (Wanda \& Warms, 2011). Assisting the students to stay focused in their studies is one of the purposes of the guidance counselors, and teachers must also do the same.

Unlike other studies that highlight relationship-centered teaching classroom (Milner, 2018), being model or social referent for students (Hendrickx et al., 2016), and facilitating dialogues (Parker \& Bickmore, 2020) in addressing racial tensions, this study revealed that different roles of teachers such as adviser, peacemaker, listener, and guidance counselor are effective in addressing cultural indifferences in the classroom. Apart from teaching, they are expected to perform those roles to preserve a conducive classroom environment for learning.

The teachers' roles as advisers, peacemakers, guidance counselors, and listeners help them mediate cultural clashes by avoiding cultural discrimination. Teach- 
ers could instill in the students the need to avoid cultural discrimination and empower love and unity. They could strengthen their discussions on the fairness of cultures among them. Teachers have a role in teaching the students about cultural discrimination. When there are cases of cultural indifference, they have to explain to both parties the need to flee from it since no culture is above others to prevent them from quarreling again (Thomas \& Brown, 2011). Teachers should emphasize that every culture is essential and significant in society.

The teachers want to establish peace learning environment. Hence, they solve cultural indifference in the classroom. In promoting a peaceful learning environment, it is also relevant to nurture the social support that involves a good relationship of the students to their teachers, parents, classmates, best friends, and other people in the school (Mares, Jezek, \& Tomasek, 2005). Teachers' roles as advisers, peacemakers, listeners, and guidance help them achieve a peaceful learning environment. The learning environment is a factor in facilitating learning for the students. The learning environment is a factor in transmitting knowledge to the students. Thus, teachers need to find ways to maintain it peacefully (Sulkowski \& Deakin, 2009). The roles of the teachers are significant in order to maintain a peaceful learning environment.

\section{Conclusion}

Schools are institutions where students could learn, gain knowledge, and develop their functions to become responsible individuals in society. These are also institutions that teach students the values and good manners to become helpful in the community. Teachers ensure that these are met by performing their functions. Teachers perform their tasks by playing advisers, peacemakers, listeners, and guidance counselors. These roles are tied up with a responsibility that helps to solve cultural indifference in the classroom. It helps the teachers to perform their functions by making a conducive learning environment. It also reduces cultural discrimination and establishes a peaceful learning environment. As this research-explored the teachers' roles in preserving harmony in the classroom, future researchers can explore the encountered challenges in promoting harmony among diverse students. 


\section{References}

Ballada, C.J.A. (2014). The development and validation of positive school scale, Educational measurement and evaluation review, 5, 55-74. Retrieved from https://ejournals. ph/article.php?id=6545.

Banks, J. A., \& Banks, C. A. M. (Eds.). (2019). Multicultural education: Issues and perspectives. John Wiley \& Sons.

Cuyjet, M. J., Howard-Hamilton, M. F., \& Cooper, D. L. (Eds.). (2012). Multiculturalism on campus: Theory, models, and practices for understanding diversity and creating inclusion. Stylus Publishing, LLC.

Emmerová, I., \& Kohútová, J. (2017). Manifestations of Pupil Aggression towards Teachers in Elementary and Secondary Schools. The New Educational Review, 50(4), 17-25. DOI: 10.15804/tner.2017.50.4.01

Garcia, A., Bongolan, V., Nuevo, J., Proleta M., Malaborbor, P., Gamboa, D., ... \& Hilario, D. (2011). Research: Simplified guide to thesis writing. Manila, Philippines: Booklore Publishing Corporation.

Hendrickx, M.M.H.G., Mainhard, M.T., Boor-Klip, H.J., Cillessen, A.H.M, \& Brekelmans, M. (2016). Social dynamics in the classroom: Teacher support and conflict and the peer ecology. Teaching and Teacher Education, 53, 33-40. http://dx.doi.org/10.1016/j. tate.2015.10.004.

Kleiman, S. (2004). Phenomenology: To wonder and search for meanings. Nurse researcher, 11 (4), 7-19. DOI: 10.7748/nr2004.07.11.4.7.c6211.

Malakolunthu, S., Siraj, S., \& Rengasamy, N.C. (2010). Multicultural Education as a reform initiative: Reconstructing teacher preparation for Malaysian "vison schools", The Asia-Pacific Education Researcher, 19(3), 453-464. Retrieved from https://ejournals.ph/ article.php?id=4041.

Mapuranga, B., \& Bukaliya, R. (2014). Multiculturalism in schools: An appreciation from the teachers' perspective of multicultural education in the Zimbabwean school system. International Journal of Humanities Social Sciences and Education, 1(2), 30-40. Retrieved from https://bit.ly/2O1GMtl.

Mares, J., Jezek, S., \& Tomasek, F. (2005). CASSS-CZ: the Czech Version of the Social Support Questionnaire for Children and Adolescents. The New Educational Review, 5, 11-25. https://tner.polsl.pl/dok/volumes/tner_1_2005.pdf

Milner, H. R. (2018). Relationship-Centered Teaching: Addressing Racial Tensions in Classrooms. Kappa delta pi record, 54(2), 60-66. https://doi.org/10.1080/00228958.20 18.1443646 .

Moustakas, C. (1994). Phenomenological research method. Thousand Oaks. CA: Sage.

Ouano, J., Buot, N.R., Conway, G.D., \& Dela Rosa, E.L. (2013). A measure of the experience of being bullied: An initial validation in Philippine School, Philippine journal of counseling Psychology, 1, 14-27. Retrieved from https://ejournals.ph/article.php?id=6817.

Parker, C. \& Bickmore, K. (2020). Classroom peace circles: Teachers' professional learning and implementation of restorative dialogue. Teaching and Teacher education, 95, 1-10. https://doi.org/10.1016/j.tate.2020.103129. 
Perso, T.F. (2004) Cultural Responsiveness and School Education: With particular focus on Australia's First Peoples; A Review \& Synthesis of the Literature. Darwin Northern Territory, Australia: Menzies School of Health Research, Centre for Child Development and Education.

Ramirez, M. (2006). Cultural diversity and education in an increasingly globalizing world (from the perspective of a 'developing country'). Pontifical Academy of Sciences, Extra Series 28. Retrieved from https://bit.ly/3iMSG8L.

Rychly, L., \& Graves, E. (2012). Teacher characteristics for culturally responsive pedagogy. Multicultural Perspectives, 14(1), 44-49. Doi:10.1080/15210960.2012.646853.

Sulkowski, N. B., \& Deakin, M. K. (2009). Does understanding culture help enhance students' learning experience? International Journal of Educational Research, 21 (2), 154-166. Doi: 10.1108/09596110910935651.

Tawagon, M. (2008). Roots of Mindanao conflict: An analysis. The Journal of History, 54(1), 1-1. Retrieved from https://ejournals.ph/article.php?id=5323\#comment521.

Thomas, D., \& Brown, J. S. (2011). A new culture of learning: Cultivating the imagination for a world of constant change. TN: LaVergne.

Wanda, S., \& Warms, R. L. (2011). Cultural anthropology (10 ${ }^{\text {th }}$ ed.). Belmont, CA: Wadsworth Cengage Learning.

Warikoo, N. (2009). Cultural explanations for racial and ethnic stratification in academic achievement: A call for a new and improved theory. Review of Educational Research, 79 (1), 366-394. Retrieved from https://bit.ly/38CQn3g.

Welton, D. (2000). The other Husserl: The horizons of transcendental phenomenology. Indiana University Press.

Yang, D., Olesova, L., \& Richardson, J. C. (2010). Impact of cultural difference on students' participation, communication and learning in an online environment. Journal of Educational Computing Research, 43 (2), 162-182. Retrieved from https://bit.ly/2Wd3DXx.

Zembylas, M. (2010). Teachers' emotional experiences of growing diversity and multiculturalism in schools and the prospects of an ethic of discomfort. Teachers and Teaching: theory and practice, 16(6), 703-716. Doi: 10.1080/13540602.2010.517687.

Zhang, J. (2010). Technology-supported learning innovation in cultural contexts. Educational Technology Research and Development, 58 (2), 229-243. Retrieved from https:// bit.ly/3e4ad8x. 